\title{
Micromorphological structure of maritime antarctic cryosols (King-George and Livingston Islands, West Antarctica)
}

\author{
Evgeny Abakumov ${ }^{1 *}$, Alexey Lupachev ${ }^{2}$, Rositsa Yaneva ${ }^{3}$, Miglena \\ Zhiyanski $^{3}$
}

${ }^{1}$ Saint-Petersburg State University, 7/9 University Embankment, St. Petersburg, 199034, Russia

${ }^{2}$ Institute of Physicochemical and Biological Problems of Soil Science, Russian Academy of Sciences, 2/2 Institutskaya st., Pushchino, 142290, Russia

${ }^{3}$ Forest Research Institute, Bulgarian Academy of Sciences, 132 "Kl. Ohridski" Blvd., 1756 Sofia, Bulgaria

\begin{abstract}
Cryosols of the Antarctic maritime area are much different from the continental ones. The relatively moderate climate conditions in Maritime Antarctica and a strong interaction between the biotic and abiotic environment are drivers for more intensive soil formation processes than in the continental regions. Soil formation studies from the Maritime Antarctica are, however, rather rare. Therefore, micromorphological investigations on polar soils can contribute to more comprehensive information on soil genesis in Antarctica. In this study, we applied the micromorphological study of thin sections from soil micromonoliths to assess the intensity and trends of the pedogenic processes in selected soils from two adjacent islands of the South-Shetland archipelago: King George Island and Livingston Island. The results obtained show that regional lithology and the origin of the incoming organic matter mainly determine the micromorphological structure of the local soils. Soil matrix micromorphological properties and features (mineralogical content, weathering stage and even partly grain-size distribution) are mainly defined by pyroclastic particles due to recent and ancient volcanic eruptions. The presence of rounded grains and aggregated mineral particles is the evidence of marine origin of the sediments. Ornithogenic soils show the clear evidence of the organic plasma formation and mineral particles aggregation via the zoogenic organic substances provided by penguins which is a unique specifics of the maritime Antarctic soils.
\end{abstract}

Key words: Antarctica, soils, micromorphology, origin

DOI: $10.5817 / \mathrm{CPR} 2021-2-22$

Received April 5, 2021, accepted January 23, 2022.

*Corresponding author: E. Abakumov <e abakumov@mail.ru>

Acknowledgements: This work was supported by Russian Foundation for Basic Research, project No 19-05-50107 and Saint Petersburg State University Internal Grant for the Modernization of Scientific Equipment No. 1.40.541.2017. The participation in the $28^{\text {th }}$ BAE was realized within the scope of the bilateral project Assessment of the regional contribution of soils of maritime antarctica islands to global carbon balance with evaluation of stabilization and humification rate of organic matter (contract No. KP 06-Russia-29/28.09.2019 RFB bolg-a-19-54-18003) at the National Science Fund, Ministry of Education and Science. The development of the projects would not be possible without the collaboration with the National Center for Polar Studies - Sofia University St. Kliment Ohridski (and Bulgarian Antarctic Institute) and the logistical support during the 28th Bulgarian Antarctic Expedition. Authors thank Ivan Alekseev for assistance in field works on King-George Island. Authors thank Christo Pimpirev and Dragomir Matveev for their help in field research. 


\section{Introduction}

Soils of Antarctica have been investigated during the last century in various aspects: evolution, geography, biology, chemistry, weathering rates, mineralogy and physics. The last aspect was studied much lesser than the other ones. Despite the facts that soils occupy only about $0.50 \%$ of the total area in Antarctica and soil areas are mainly distributed in coastal lands, investigation of the pedogenesis rate is quite important for the interpretation of factors, forming the soils of Antarctica. Antarctic ice-free areas have emerged from retreating glaciers during the past few thousand years and glacial erosion is still the dominant land-forming factor. Therefore, the newly-deglaciated ground is mostly barren of any visible vegetation and is primarily covered with glacier till, unsorted rock rubble, gravel and scattered erratic boulders. At the same time, paraglacial landscape nowadays is colonized by vegetation cover due to transportation of the propagules by sea birds. This appears even in case of remote inland nunataks and rocks, surrounded by the ice-sheets. Thus, the biogenic-abiogenic interactions are the main factor of soil mineral part development in both, coastal and inland areas of various environments of Antarctica.

Due to the higher air temperature and the amount of liquid precipitation reported for the subantarctic region, the soils are strikingly different from those described in coastal oases of East Antarctica (Bockheim et al. 2015). Frequent transitions of soil temperature through zero values, frequent freezing-thawing cycles of soil may cause accelerated degradation of parent materials. At the same time, the availability of moisture and high microbiological activity increase the role of biological and chemical weathering of rocks, as well as the content of organic carbon in soils. In addition, all the conditions mentioned above lead to the formation of clay secondary minerals. Antarctic soils are mainly coarse textured with the content of coarse fraction about $80-90 \%$ and fine earth about 10-20\% (Jaap et al. 1993, Abakumov 2010). Some Antarctic soils of dry inland oases show only $1-3 \%$ of the fine earth. In contrast, some soils derived from moraines and marine sediments show the content of fine earth about 60 or even 87\% (Abakumov et al. 2010, 2011, 2014). This means that soil texture origin depends mainly on the composition of parent materials. The second factor of soil texture formation is the weathering process, expressed in biogenic-abiogenic interaction in soils (Glazovskaya 1958, 2002, Oliva and Ruiz-Fernández 2016, Mergelov et al. 2012, 2018).

Key soil properties and pedogenic processes have been investigated in details for the region of the Antarctic Peninsula (Beyer et al. 2000, Simas 2004, 2006; Parnikoza et al. 2016, Lupachev et al. 2020). It was established that soil formation here is more intensive than in the continental part due to a longer period of presence of vegetation cover and relatively higher rate of humidity and average air temperature (Campbell and Claridge 1987, Beyer et al. 2000, Bockheim et al. 2015). Nevertheless, micromorphological surveys of soils are very rare, even for the soils of the Antarctic Peninsula (Vlasov et al. 2005). At the same time, an application of micromorphological method can contribute additional information and can help in the interpretation of the genesis of the modern soils of Antarctica.

Thus, the aim of this work is to assess the specificity of pedogenetic processes in selected soils of South Shetland archipelago with the use of micromorphological method in thin sections, made from soil micromonoliths. 


\section{Material and Methods}

\section{Regional setting}

Study sites are located in the vicinity of the Russian Antarctic station Bellingshausen (Fildes Peninsula, the south-west part of King-George Island), and in the surroundings of St Kliment Ohridski station (Livingston Island). Both islands are part of the South Shetland Islands archipelago in West Antarctica. Pedogenic, geomorphological and environmental characteristics were described in numerous previous investigations. Soils of the Maritime Antarctica are characterized by thicker and more developed profiles in comparison with soils of continental part (Campbell and Claridge 1987, Bockheim et al. 2015). The dominant type of mineral soils on the Fildes Peninsula are Cryosols (Lupachev et al. 2020) - covering nearly half (42.9\%) of its total area. Flat watersheds are mainly occupied by Protic Arenosols (Turbic) $(22.9 \%)$. Leptosols are mainly represented by the Lithic (Ochric) subgroup covering $13.8 \%$ of the area. Fluvisols are locally developed in the tidal zone $3.3 \%$ of the total area) and are represented by the Tidalic (Skeletic) subgroup. Also, numerous areas of bird-affected soils are distributed within the areas of different geomorphological properties (the Fildes Peninsula). Specific morphology allows distinguishing two major ornithogenic soil types at the Fildes Peninsula: Hyperskeletic Cryosols (Ornithic and Protoornithic) and Leptosols (Protoornithic). Hyperskeletic Cryosols are found in recent and/or abandoned penguin rookeries with a relatively thick profile (above $50 \mathrm{~cm}$ ) highly enriched in allochthonous ornithogenic material. They can be formed under the specific vegetation cover consisting of the bacterial mats and nitrophilous algae (e.g. Prasiola crispa subsp. antarctica (Kützing) Knebel). Flying birds' influence results in the development of Leptosols (Protoornithic) at the coastal localities on steep and rocky cliffs of abundant small islands, where flying sea birds (gulls, petrels, skuas, and others) are nesting and molting.

Soil cover of Livingston Island is more homogenous in spatial aspect, thus soils here are concentrated in coastal part on the marine terraces and hills ranging between 23 to $71 \mathrm{~m}$. The most extinctive soil profiles are located on friable deposits of marine origin with admixture of pyroclastic material of volcanic origin. The area of the island is $845 \mathrm{~km}^{2}$ and only $10 \%$ is ice- and snow-free in the period of the Antarctic summer (from October to March). The island is formed from three structural terraces. The uppermost one is $2 \mathrm{~km}$ thick and, in fact composed of crystallized andesite and basalt lava, mixed with sandstones and conglomerates. Three physico-geographical sectors can be distinguished on the island: eastern, covered by ice; central, characterized by high ice heaps and platforms; and western - plain-like almost without ice cover. The terrains where the glaciers have retreated are covered by moraines (Sokolovska et al. 2015). In the study area, the meteorological conditions, landslides and water and wind erosion in particular play leading role in the formation of the present landscape. On the plain surfaces, the weathered rock base mixes with tephra and creates fields with a typical periglacial deposits of the weathered material (Kenderova and Baltakova 2015). On the slopes with western and southwestern exposure, the weathering processes of the rocks develop with higher intensity. A typical relief-forming process for the steep slopes of the Bulgarian beach is cryosolifluction (gelifluction), which is observed at slopes steeper than $10^{\circ}$ in the area of the chapel St. Ivan Rilski and the Bulgarian beach (Kenderova and Baltakova 2015). The formation and development of the soils is related to the time of 
retreat of the glacier and the period during which the newly formed soil remains exposed. In turn, the soil formation process takes place in a permafrost environment (Oliva and Ruiz-Fernández 2016).
In this study we describe 6 soil profiles on King George Island and 2 soil profiles on Livingston Island (Table 1, Fig. 1, 2) and use the soil taxonomy according to WRB 2015 ([1] - IUSS, 2015).

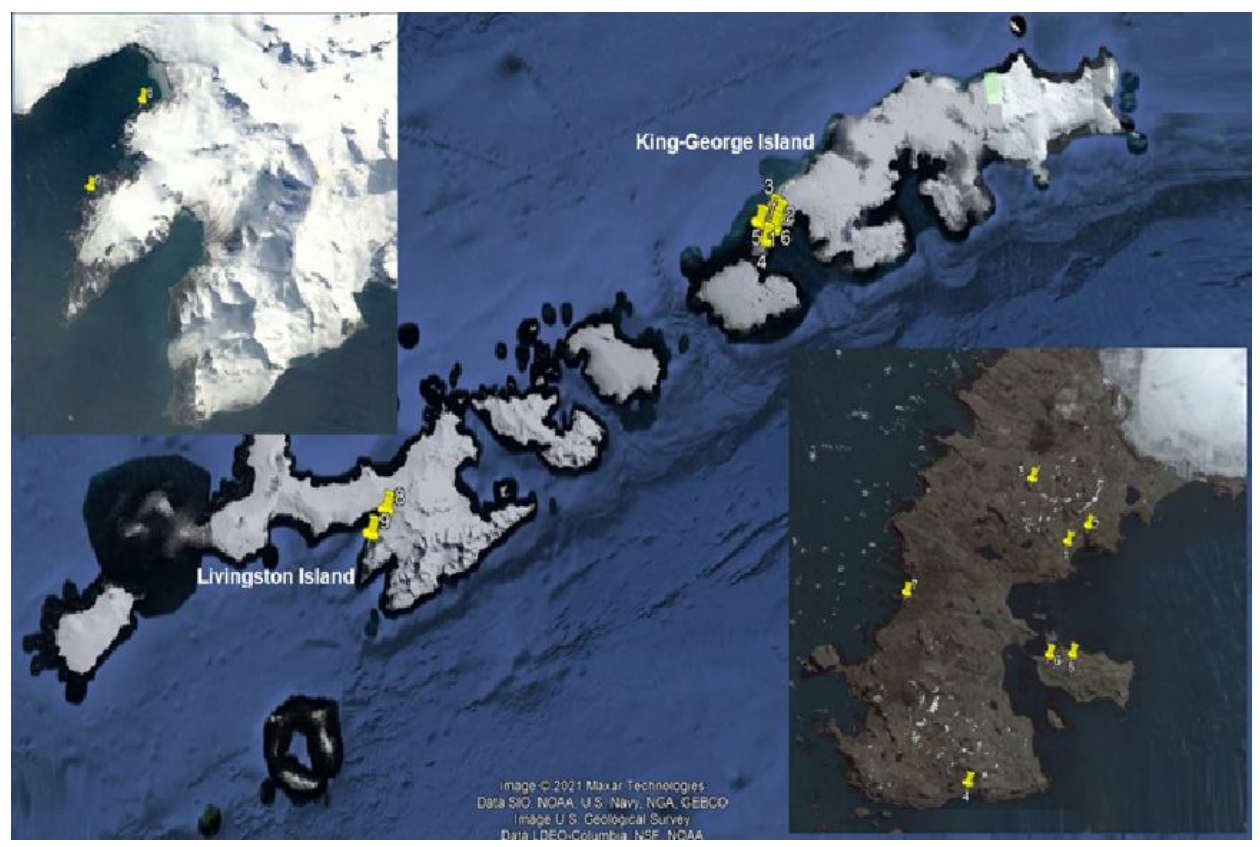

Fig. 1. Field location of soil study sites.

\section{Thin section and microscope analyses}

Thin sections $(0.03 \mathrm{~mm})$ were prepared using the regular grinding wheel and fine (0.8-1.6 microns) abrasive paste from the micromonoliths of soils, sampled during several field campaigns (Evgeny Abakumov $\left(61^{\text {st }}\right.$ and $65^{\text {th }}$ Russian Antarctic Expedition-RAE), Alexey Lupachev ( $57^{\text {th }}$ RAE), Ivan Alekseev (63 ${ }^{\text {th }}$ RAE) and Rositsa Yaneva and Evgeny Abakumov (28 $8^{\text {th }}$ Bulgarian Antarctic expedition 2019/2020). Samples were air dried and then saturated with epoxy resin. Thin sections were investigated with use of optical polarization microscopes Leica DM750P (SPbGU) and Carl Zeiss Axioscope A1 with Axiocam
MR5 camera (IPCBPSS, Puschino Scientific Centre). The following soil micromorphological features were investigated: grain sizes and mineralogical composition, soil microfabric, elements of microstructure and character of organic matter, appearance and forms of plasma (organic, clay). The terminology used in this paper is published by Parfenova and Yarilova (1977), Stoops (2003), Gagarina (2004) and Gerasimova et al. (2011), where details of the micro-organization of soil were described and classified in details (Stoops and Eswaran 1986, Stoops 2003, 2009). 


\begin{tabular}{|c|c|c|c|c|c|c|}
\hline $\begin{array}{c}\text { Sample } \\
\text { code }\end{array}$ & $\begin{array}{c}\text { Soil type } \\
\text { (WRB, 2015) }\end{array}$ & Location & $\begin{array}{l}\text { Vegetation } \\
\text { type }\end{array}$ & Coordinates & $\begin{array}{c}\text { TOC, } \\
\%\end{array}$ & \begin{tabular}{|c|} 
pH \\
water \\
extr
\end{tabular} \\
\hline 1 & $\begin{array}{l}\text { Technosols } \\
\text { Transportic } \\
\text { Lithosol } \\
\text { Ornithic } \\
\text { Hyperskeletic }\end{array}$ & $\begin{array}{l}\text { King George, } \\
\text { Oil storage }\end{array}$ & $\begin{array}{l}\text { Fragmentary } \\
\text { mosses and } \\
\text { lichens }\end{array}$ & 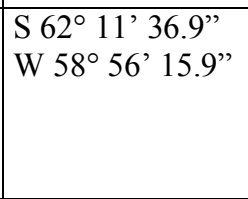 & 0.52 & 4.55 \\
\hline 2 & $\begin{array}{l}\text { Lithosol Histic } \\
\text { Lithosol } \\
\text { Ornithic } \\
\text { Hyperskeletic }\end{array}$ & $\begin{array}{l}\text { King George, } \\
\text { Background } \\
\text { ecosystem }\end{array}$ & $\begin{array}{l}\text { Histic moss } \\
\text { derived } \\
\text { materials }\end{array}$ & $\begin{array}{l}\text { S } 62^{\circ} 11^{\prime} 27.9 ” \\
\text { W } 58^{\circ} 55^{\prime} 47.9^{\prime \prime}\end{array}$ & 1.25 & 5.66 \\
\hline 3 & $\begin{array}{l}\text { Lithosol } \\
\text { Lithosol } \\
\text { Ornithic } \\
\text { Hyperskeletic }\end{array}$ & $\begin{array}{l}\text { King George, } \\
\text { Temporary } \\
\text { water pond, } \\
\text { costal part }\end{array}$ & $\begin{array}{l}\text { Organic mate- } \\
\text { rial of algae } \\
\text { origin, sublay- } \\
\text { ered by round- } \\
\text { ed mineral } \\
\text { particles }\end{array}$ & $\begin{array}{l}\text { S } 62^{\circ} 10^{\prime} 59.5^{\prime \prime} \\
\text { W } 58^{\circ} 57^{\prime} 01.3^{\prime \prime}\end{array}$ & 2.67 & 5.22 \\
\hline 4 & $\begin{array}{l}\text { Lithosol Histic } \\
\text { Lithosol } \\
\text { Ornithic } \\
\text { Hyperskeletic } \\
\text { Tidalic } \\
\end{array}$ & $\begin{array}{l}\text { King George, } \\
\text { Coastal part of } \\
\text { marine terrace }\end{array}$ & $\begin{array}{l}\text { Moraine } \\
\text { material, } \\
\text { covered by } \\
\text { histic mosses }\end{array}$ & $\begin{array}{l}\text { S } 62^{\circ} 13^{\prime} 46.4^{\prime \prime} \\
\text { W } 58^{\circ} 58^{\prime} 36.4^{\prime \prime}\end{array}$ & 1.89 & 5.30 \\
\hline 5 & $\begin{array}{l}\text { Lithosol } \\
\text { Ornithic } \\
\text { Hyperskeletic }\end{array}$ & $\begin{array}{l}\text { King George, } \\
\text { Penguin rook- } \\
\text { ery. Poorly } \\
\text { decomposed } \\
\text { guano } \\
\end{array}$ & No vegetation & $\begin{array}{l}\mathrm{S} 62^{\circ} 12^{\prime} 40.0^{\prime \prime} \\
\text { W } 58^{\circ} 56^{\prime} 16.6^{\prime \prime}\end{array}$ & 6.78 & 4.80 \\
\hline 6 & $\begin{array}{l}\text { Lithosol } \\
\text { Postornithic } \\
\text { Hyperskeletic }\end{array}$ & $\begin{array}{l}\text { King George, } \\
\text { Abandoned } \\
\text { penguin rook- } \\
\text { ery. Well de- } \\
\text { composed gua- } \\
\text { no mixed with } \\
\text { plant organic } \\
\text { remnants }\end{array}$ & \begin{tabular}{|l} 
Prasiola \\
crispa, \\
Deschampsia \\
antarctica
\end{tabular} & $\begin{array}{l}\text { S } 62^{\circ} 12^{\prime} 40,0^{\prime \prime} \\
\text { W } 58^{\circ} 56^{\prime} 47,1^{\prime \prime}\end{array}$ & 5.70 & 4.90 \\
\hline 7 & $\begin{array}{l}\text { Lithosol } \\
\text { Ornithic } \\
\text { Hyperskeletic }\end{array}$ & $\begin{array}{l}\text { King George, } \\
\text { Penguin rook- } \\
\text { ery. Poorly } \\
\text { decomposed } \\
\text { guano } \\
\end{array}$ & No vegetation & \begin{tabular}{|l|l}
$\mathrm{S} 62^{\circ} 12^{\prime}$ & $3.10^{\prime \prime}$ \\
$\mathrm{W} 58^{\circ} 59^{\prime}$ & $51.7^{\prime \prime}$
\end{tabular} & 6.81 & 5.10 \\
\hline 8 & Lithosol & $\begin{array}{l}\text { Livingston, } \\
\text { Playa Bulgara }\end{array}$ & $\begin{array}{l}\text { Few cushions } \\
\text { of Deshampsia } \\
\text { antarctica }\end{array}$ & \begin{tabular}{|l|} 
S $62^{\circ} 38^{\prime} 06.9^{\prime \prime}$ \\
W $60^{\circ} 21^{\prime} 14.7^{\prime \prime}$
\end{tabular} & 1.19 & 5.95 \\
\hline 9 & $\begin{array}{l}\text { Lithosol Histic } \\
\text { Ornithic }\end{array}$ & $\begin{array}{l}\text { Livingston, } \\
\text { Caletta } \\
\text { Agrentina }\end{array}$ & $\begin{array}{l}\text { Grasses, } \\
\text { mosses and } \\
\text { ornithic } \\
\text { presence }\end{array}$ & $\begin{array}{l}\text { S } 62^{\circ} 40^{\prime} 8.50^{\prime \prime} \\
\text { W } 60^{\circ} 24^{\prime} 8.0^{\prime \prime}\end{array}$ & 3.47 & 5.75 \\
\hline
\end{tabular}

Table 1. Thin sections sampling description. 


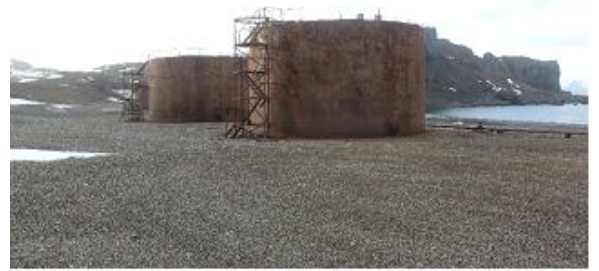

1

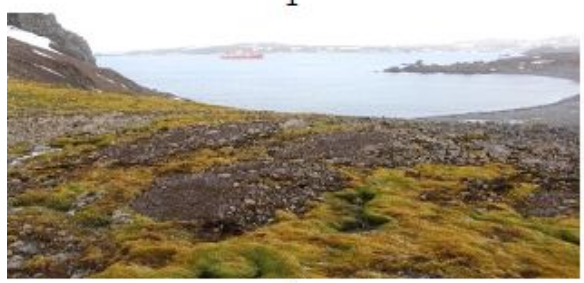

2

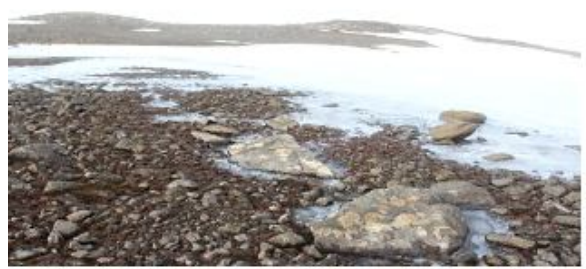

3

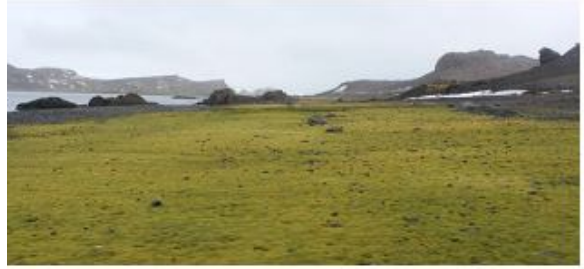

4

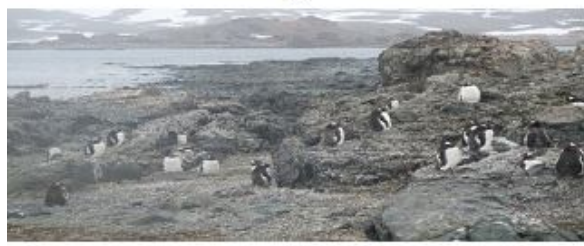

5

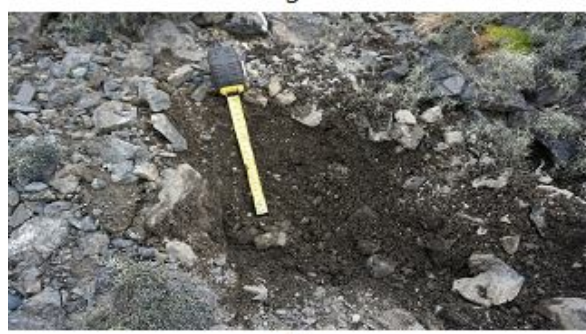

7

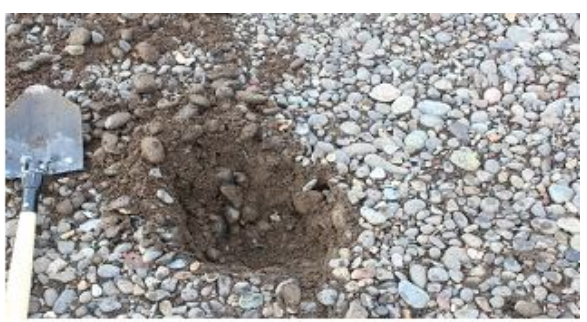

1

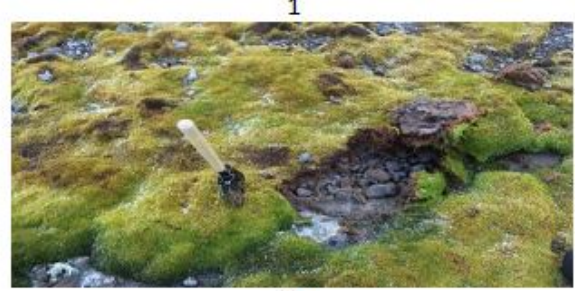

2

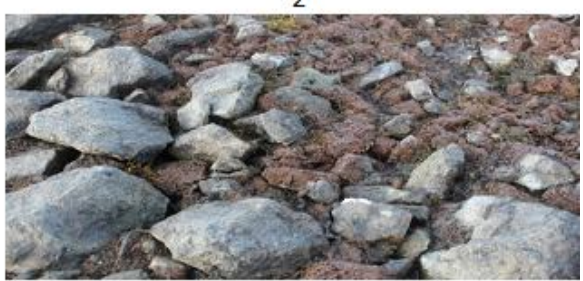

3

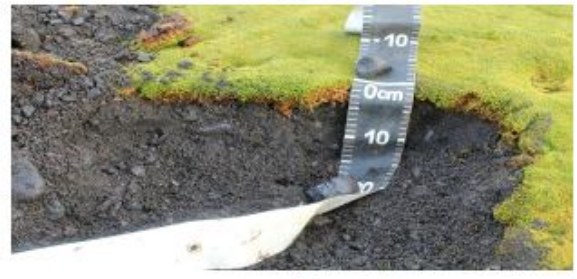

4

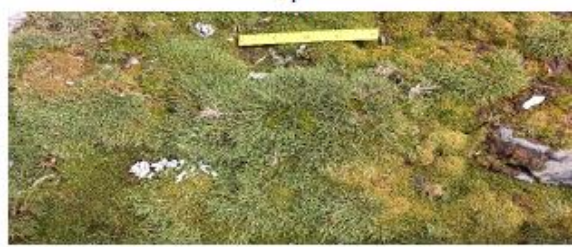

6

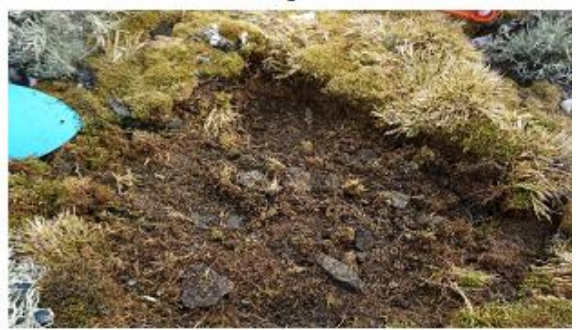

8

Fig. 2. Sample plots on the King George Island. Note: 1-8 - numbers of plots. 


\section{Results and Discussion}

Microphotographs of sampled soils are given in Fig. 3-8. The sample 1 - transportic gravel material in the vicinity of Russian gasoline storage (Neftebaza) was expected to possess some technogenic features. Nevertheless, the thin sections showed only rounded form of mineral particles and no admixture of easy weathering mineral (Fig. 3). The last feature can be explained by leaching of micas and other micro particles form soil during trans-
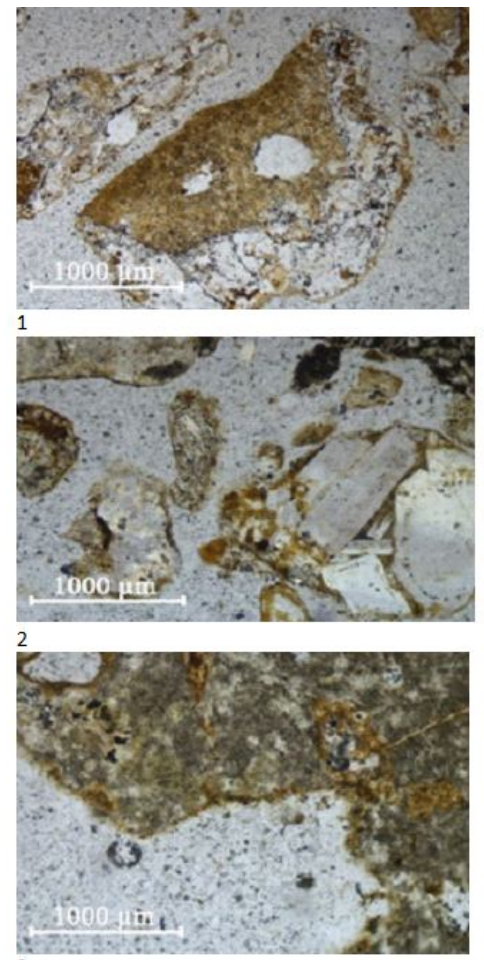

2

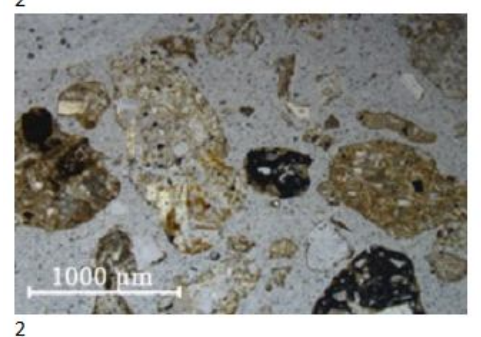

portation and resedimentation of materials, used for engineer constructions.

Histic soils with mineral layer are presented by rounded mineral grains with admixture of mica and feldspars (sample 3). Sample is presented by less rounded particles with well-developed porous media. Sample 3 also contains the rounded pyroclastic particles. There is well-expressed iron staining of the polymineral surfaces of the sample 3 .
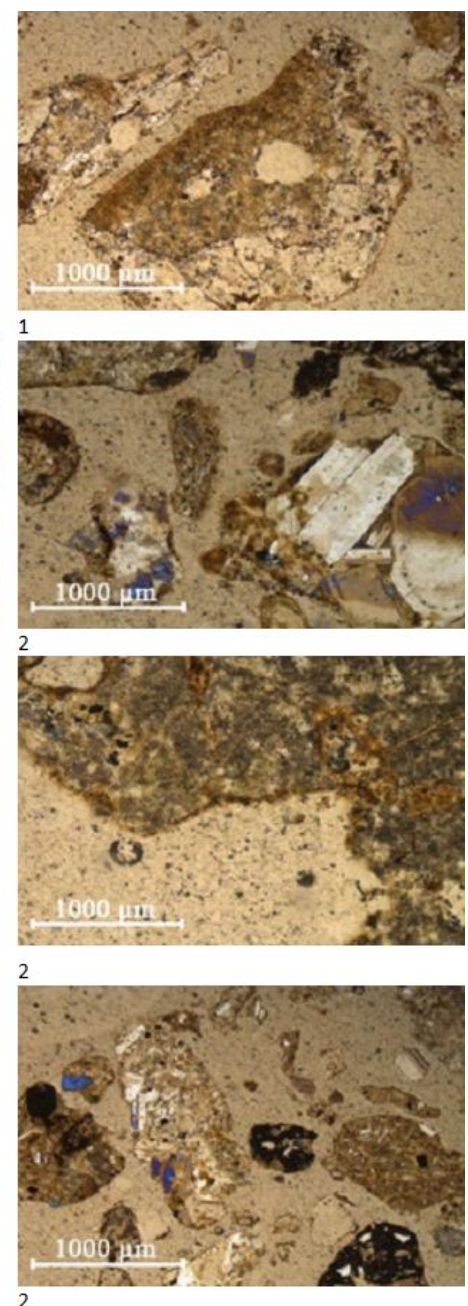

Fig. 3. Thin sections of the soil micromonoliths, King George Island. Note: samples 1-2, left - plain light, right - polarized light. 
Soil material under algae seasonal mat is presented by separate mineral and organic particles without any interaction on biogenic-abiogenic level (Fig. 4). It results from the fact that this soil body is seasonal, so-called "amphibious" (Abakumov 2011). Partially decayed organic remnants of algae are located in porous media of the mineral part of soils. These remnants fall through the mineral particles mechanically, with no organo-mineral interactions. These process is similar to processes of vertical movement of organic particles in Cryosols, described by Gubin and Lupachev (2018), but is expressed lesser in soils investigated, that in soils of Arctica. Accumulation of unaltered organic particles in porous media and cracks is quite typical also for soils of coastal and continental Antarctica (Abakumov 2014, Aba- kumov et al. 2013).

Soils under guano material have a mineral mass intensively mixed and aggregated by well decomposed guano, which does not change optical features while changing of transparent light to polarized one. This is the feature of amorphous origin of organic plasma (Kubiena 1938, 1970, 1971; Gagarina 2004). Soils of abandoned penguin rookeries are less exposed to the accumulation of the fresh guano material, but there is some accumulation of organic matter, derived from fresh organic remnants. Thus, there is a sticking of two types of organic materials. These soils demonstrate strong alteration of mineral phase of soil, exposed in sericitization of the feldspars, which is best seen in the polarized light.
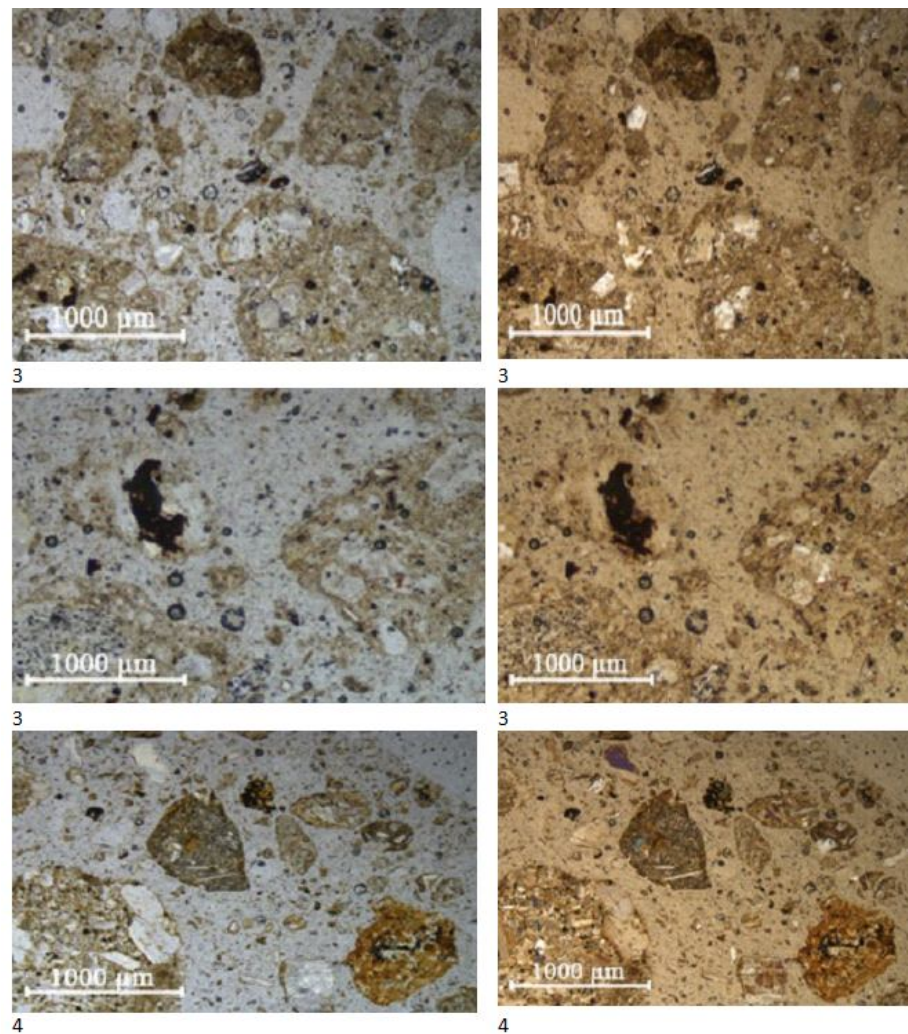

4

Fig. 4. Thin sections of the soil micromonoliths, King George Island. Note: samples 3-4, left - plain light, right - polarized light. 
As for the fresh material of moraine hill (Fig. 5), its mineralogical composition is richer than in the investigated soils. Soils of marine terraces and seasonal ponds are poorer in the mineral richness of the fine earth, than the fresh moraine. The first feature of moraine material is angular, but not rounded forms of the particles, composed
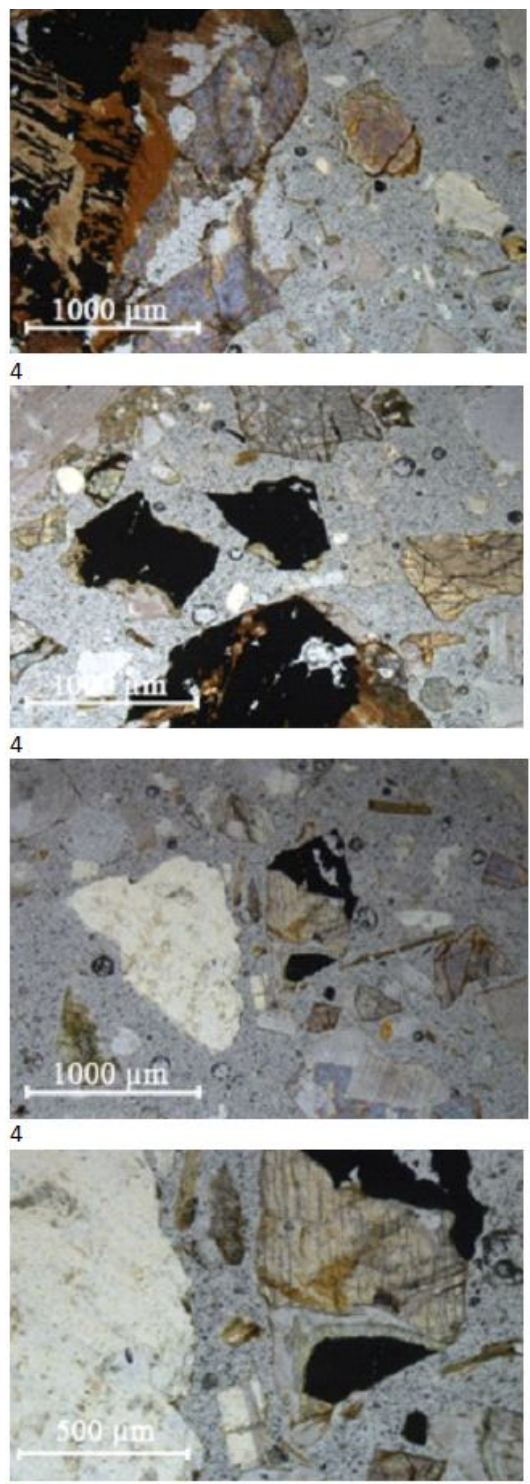

4 mainly of quartz, feldspars and dark colored pyroclastic particles, due to presence of periodic volcanic eruptions on the adjacent Livingston and Deception Islands. The angular form of grains in polar soils, normally indicates glacier origin of mineral material (Konishev and Rogov 1977, Konishchev and Rogov 2008, Sizov et al.2020).
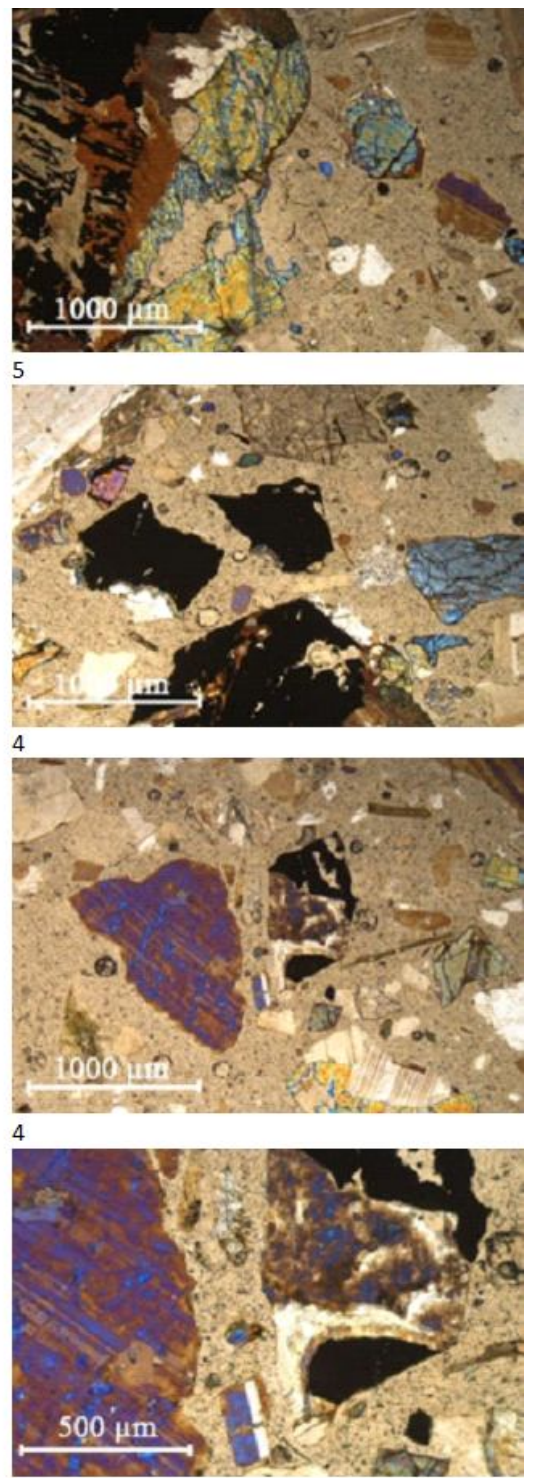

4

Fig. 5. Thin sections of the soil micromonoliths, King George Island. Note: samples 4, left - plain light, right - polarized light. 
The very specific type of the organogenic plasma is formed in the ornithogenic and postornithogenic soils under the modern and abandoned penguin rookeries is the humus-like plasma and it represents another wide-distributed example of organomineral interaction in the different environments of Antarctica (Fig. 6). It can be accumulated on the surface of the coarse grains in form of the guano and poorly decomposed ornithogenic material (fragments of feathers, eggshells, tissues and bones) as well as in form of organic colloidal plasma (Fig. 7). This type of plasma has well-expressed mobile-laminar structure with inclusions of shaggy zones (Fig. 7). It covers the grain surfaces very densely and forms thick films and wide microzones of compacted skeletal structure. In some microzones, the clots and concretions are forming and in the peripheral parts of the plasma the microscopic crystals of biogenic phosphates and sulphates are forming (Fig. 7). Plasma includes the abundant fungi hyphae and sporangiums, as well as the colonies of the unicellular algae (Fig. 7).

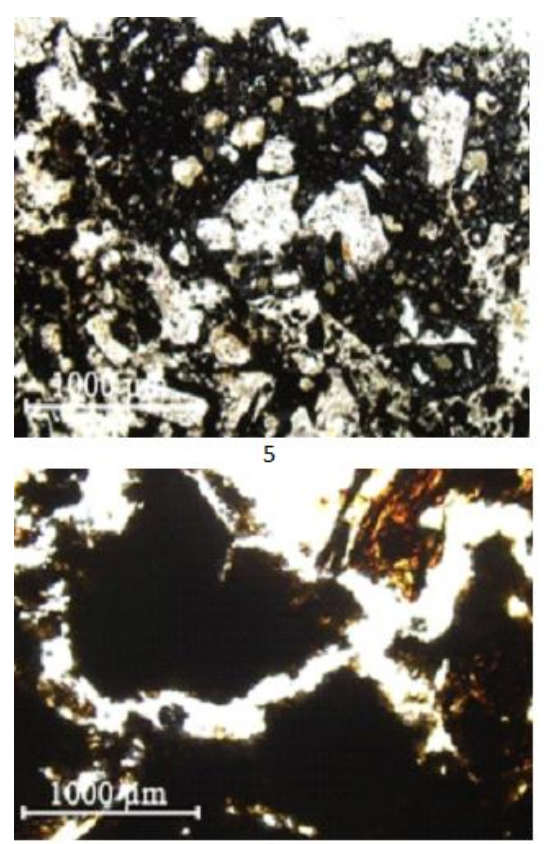

6

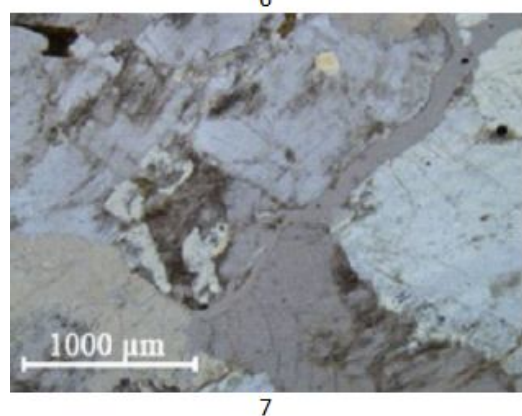

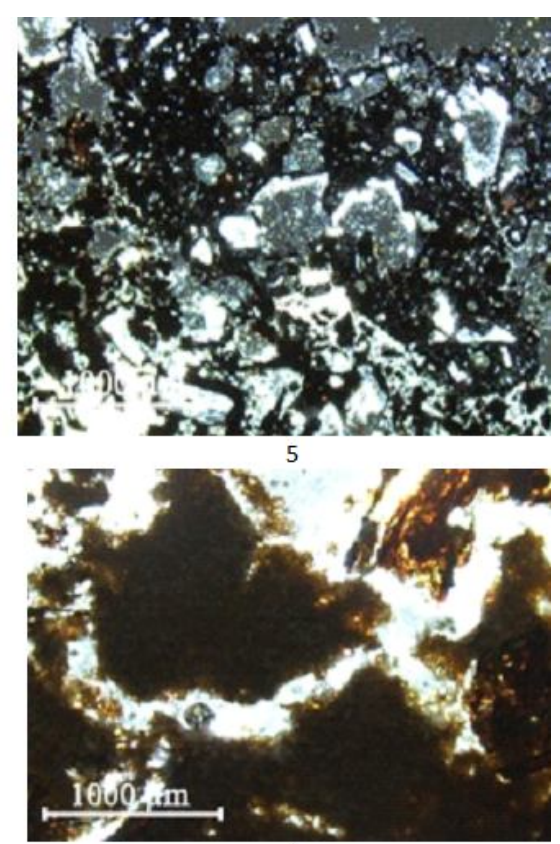

6

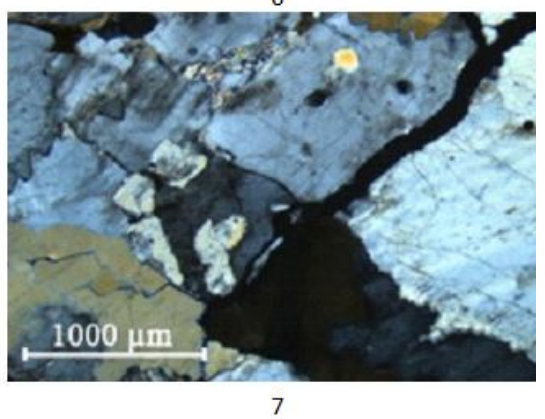

Fig. 6. Thin sections of the soil micromonoliths, King George Island. Note: samples 4-6, left - plain light, right - polarized light. 

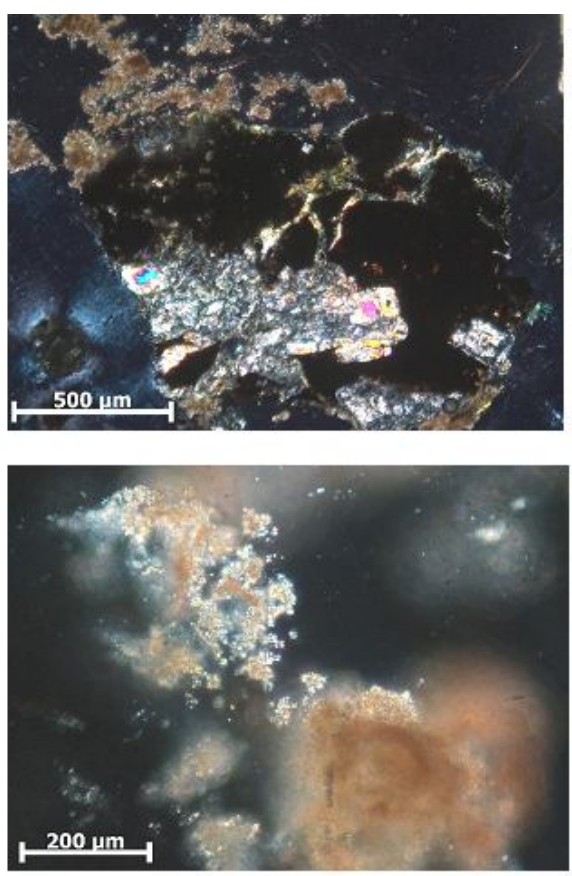
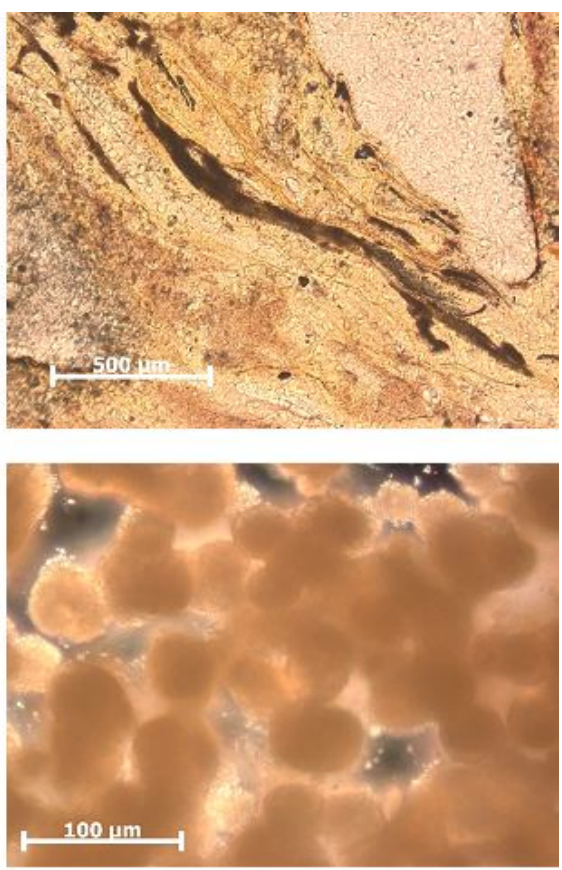

Fig. 7. Thin sections of the soil micrononoliths, King George Island. Note: sample 7, left - plain light, right - polarized light.

Micromorphology of the soils on the Livingston Island is also essentially determined by the presence of pyroclastic particles originated from the active local volcano at Deception Island, situated $35 \mathrm{~km}$ from Livingston Island. Mineral soils of Playa Bulgara contain many pyroclastic particles with admixture of few decomposed plant remnants (Fig. 8). Quartz, feldspar and polymineral grains of rounded form are characteristic for this soil. This fact as well as the presence of glauconite grains supports the idea of marine origin of the sediment.

Lithosol of the Caletta Agrentina plot (Livingston Island) is characterized by a presence of angular and slightly rounded particles of dark pyroclastic materials and iron stained grains of polymineral composition. Evident features of guano accumulation are found even in the soils under postornithic environment. Soil is characterized by increased porosity and absence of any type of plasms (Fig. 8), which indicate low degree of organo-mineral interactions and low alteration of the mineral part.

Data on micromorphology of ornithogenic soil are in well correspondence without previous data (Lupachev et al. 2020, Abakumov et al. 2013), but do not reveal features of phosphatization, as it was described by Pereira et al. (2013). That results from the fact that previous studies were conducted on current colonies with dense population effect of birds on soils, whereas soils investigated in the present study have only few evidences of ornithogenic effect. We do describe rounded form of some grains, which corresponds well to the data of Meer et al (1993), but the intensity of plasma formation in our section is less expressed. 


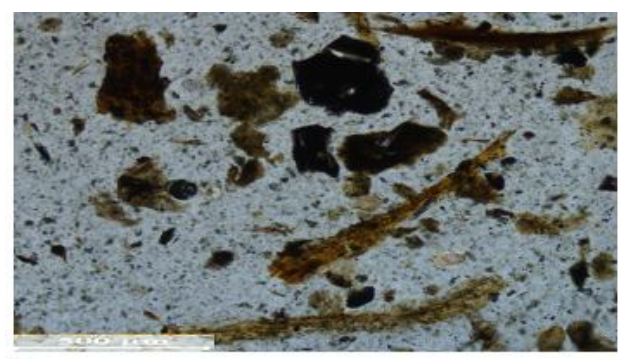

7

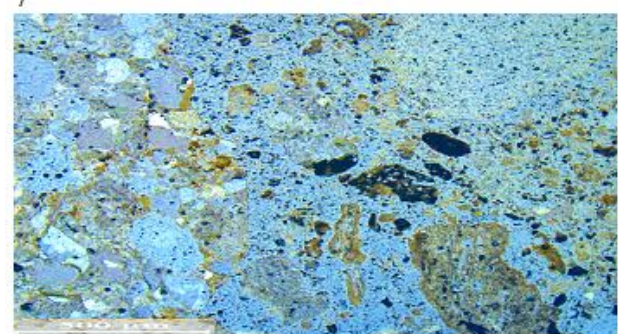

7

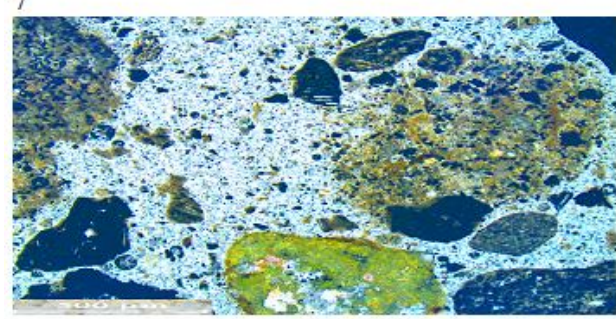

7

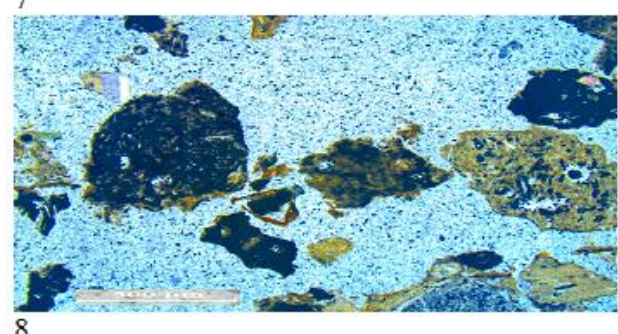

8

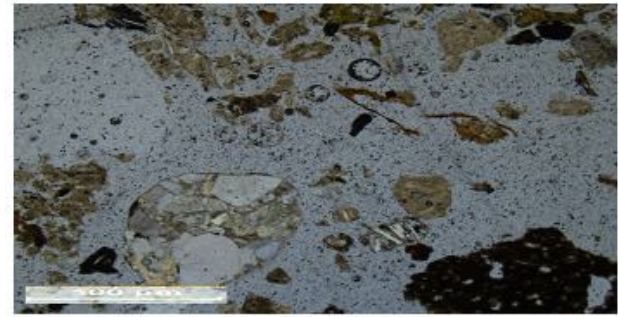

8

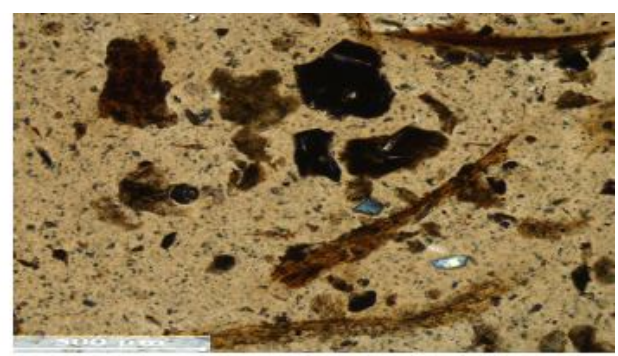

7
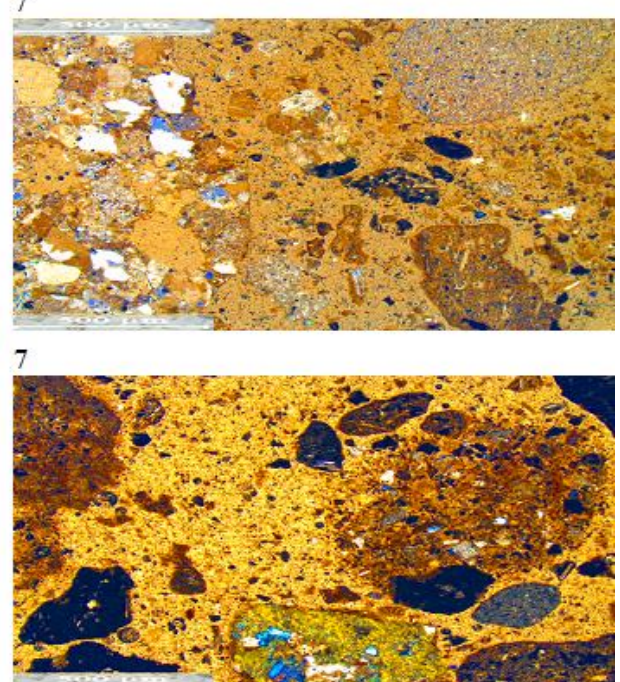

7

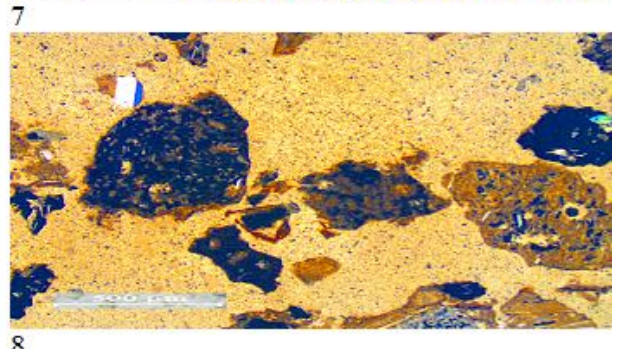

8

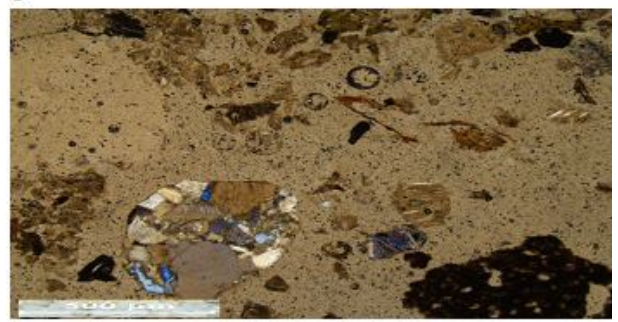

8

Fig. 8. Thin sections of the soil micromonoliths, Livingstone Island. Note: left - plain light, right - polarized light. 
The dominance of quartz and micas is marked by Sedov et al. (2019), and we can also confirm these conclusions: Antarctic soil bodies are sedimentary: fluvial (and possibly eolian) deposition of mineral material that occurs simultaneously with the growth of primitive plants (Sedov et al. 2019). Thus, the footprint of mineral and granulometric properties of the parent materials are evident in all soils investigated, which is typical not only for Antarctic soils (Sedov et al. 2019), but also

\section{Conclusions}

Soils of two adjacent islands from South-Shetland archipelago: King George and Livingston have been investigated in terms of micromorphology. It was shown that mineralogical features of parent materials have a long influence on soil properties and micromorphological features. Thus, the presence of pyroclastic material indicates intensive influence of past and recent volcanic eruptions that affected King George Island, and especially Livingston Island. There are also evident features of marine origin of parent materials: rounded form of grains with simultaneous accumulation of the glauconite. Organic matter of plant origin is not strongly altered in soils and (presented by detritus) consists of partially decomposed snippets of mosses, al- for Arctic ones (Slagoda et al. 2015). No intense pedogenic alteration of mineral mass can overlap inherited features of soil forming materials of various origin. The only process that can seriously change soil organization and morphology is the accumulation of guano (Abakumov 2014). Usually, the alteration of minerals in soils studied was expressed in top layer of $0-20 \mathrm{~cm}$ which well corresponds to data of Shmelev (2015).

gae and grasses, not associated with mineral parts. Only the guano-affected soils demonstrate formation of organic plasma and formation of aggregated of mineral particles, binded by decomposed guano. Thus, the Antarctic soil micromorphological properties are seriously affected by lithological factor in spite of high rate of the processes of biological accumulation in comparison with soils of more severe coastal and continental Antarctica. Synlithogenic accumulation of mineral particles during current and recent soil formation can be considered as pedogenic process in soils of maritime Antarctic zone. This process is well expressed in top soil 0-20 cm layer, which can be assigned as zone of intensive mineral grain alteration.

\section{References}

Aвакumov, E. V. (2010): Particle-size distribution in soils of West Antarctica. Eurasian Soil Science, 43(3): 297-304. doi: 10.1134/S1064229310030075

AваKumov, E. V. (2011): Soils of Western Antarctic. St. Petersburg, Russia. 112 p.

AваKumov, E. V. (2014): Micromorphological features of ornitogenic soil formation in Antarctica. Russian Ornithological Journal, 23(1030): 2353-2357.

Abakumov, E. V., Gagarina, E. I., Sapega, V. F. and Vlasov, D.Y. (2013): Micromorphological features of the fine earth and skeletal fractions of soils of West Antarctica in the areas of Russian Antarctic stations. Eurasian Soil Science, 46(12): 1219-1229. doi: 10.1134/S10642 29313120028

Beyer, L., PingPank, K., Wriedt, G. and Bölter, M. (2000): Soil formation in coastal continental Antarctica (Wilkes Land). Geoderma, 95(3-4): 283-304.

BockHeIM, J. (eds.)(2015): The soils of Antarctica. New York, Springer. 332 p. 
Campbell, I. B., Claridge, G. G. C. (1987): Antarctica: Soils, Weathering, Processes and Environment. Amsterdam: Elsevier. 368 p.

Gagarina, E. I. (2004): Micromorphological method of soil investigation. St. Petersburg Univ. Publ., Saint Petersburg, 156 p. (In Russian).

Gerasimova, M. I., Kovda, I. V., LebedeVA M. P. and Tursina, T. V. (2011): Micromorphological terms: The state of the art in soil microfabric research. Eurasian Soil Science, 44: 804-817.

GlazovskayA, M. A. (2002): Biogeochemical weathering of andesitic volcanic rocks in subantarctic periglacial conditions. Izvestiya Akademii Nauk, Seriya Geograficheskaya, 3: 39-48.

Glazovskaya, M. A. (1958): Weathering and initial pedogenesis in Antarctica. Nauchniye Doklady Vyshey Shkoly, Geologo-Georgaphicheskiye Nauki, 1: 63-76.

Gubin, S. V., LuPACheV, A. V. (2018): Suprapermafrost horizons of the accumulation of raw organic matter in tundra cryozems of Northern Yakutia. Eurasian Soil Science, 51(7): 772-781. doi: $10.1134 / \mathrm{S} 1064229318070049$

JaAP, M., Herman, J. and HöFLe, H. (1993): Micromorphological Observations on till sampies from the Shackleton Range and North Victoria Land, Antarctica. Polarforshung, 62(1): 57-65.

Kenderova, R., Baltakova, A. (2015): Geomorphological study of the Bulgarian antarctic base "St. Kliment Ohridski" area. In: Ch. Pimpirev, N. Chipev (eds): Bulgarian Antarctic Research A Synthesis, "St. Kliment Ohridski" University Press. pp. 221-236. (ISBN 978-954-07-3939-7).

KonishcheV, V. N., Rogov, V. V. (2008): The impact of cryogenesis on clay minerals. Kriosfera Zemli, 1: 51-58.

Konishev, V. V., Rogov, V. V. (1977): Micromorphology of cryogenic soils. Eurasian Soil Science, 2: 119-125.

KuBIENA, W. L. (1938): Micropedology. Ames, Iowa: Collegiate press, 243 p.

KuBIENA, W. L. (1970): Micromorphological features of Soil geography. New Jersey: Rutgers University Press, $254 \mathrm{p}$.

KuBIENA, W. L. (1971): Ergebnisse einer bodenkundliehe Studienreise in die Antarktis. Hamburg Geographical Studies, 24: 349-373.

LupacheV, A. V., Gubin, S. V. and ABaKumov, E.V. (2020): Levels of biogenic-abiogenic interaction and structural organization of soils and soil-like bodies in Antarctica. Lecture Notes in Earth System Sciences, pp. 481-500. doi: 10.1007/978-3-030-21614-6_26

Mergelov, N. S., Gory achkin, S. V., Shorkunov, I. G., Zazovskaya, E. P. AND Cherkinsky, A. E. (2012): Endolithic pedogenesis and rock varnish on massive crystalline rocks in East Antarctica. Eurasian Soil Science, 45(10): 901-917. doi: 10.1134/S1064229312100067

Mergelov, N., Mueller, C. W., Prater, I., Shorkunov, I., Dolgikh, A., Zazovskaya, E., ShishKov, V., Krupskaya, V., Abrosimov, K., Cherkinsky, A. and Goryachrin, S. (2018): Alteration of rocks by endolithic organisms is one of the pathways for the beginning of soils on Earth. Scientific Reports, 8(1): 3367. doi: 10.1038/s41598-018-21682-6

Oliva, M., RUIZ FERnÁNDEZ, J. (2016): Geomorphological processes and frozen ground conditions in Elephant Point(Livingston Island, South Shetland Islands, Antarctica). Geomorphology, 293: 368-379. doi: 10.1016/j.geomorph.2016.01.020

Parfenova, E. I., Yarilova, E. A. (1977): Manual on Soil Micromorphology. Moscow: Nauka. $101 \mathrm{p}$.

Parnikoza, I., Abakumov, E., Korsun, S., Klymenko, I., Netsyk, M., Kudinova, A. and KozerETSKA, I. (2016): Soils of the argentine islands, Antarctica: Diversity and characteristics. Polarforschung, 86(2): 83-96.

Pereira, T. T. C., Schaefer, C. E. G. R., Ker, J. C., Almeida, C. C., Almeida, I. C. C. (2013): Micromorphological and microchemical indicators of pedogenesis in Ornithogenic Cryosols (Gelisols) of Hope Bay, Antarctic Peninsula. Geoderma, 193-194: 311-322. doi: 10.1016/ j.geoderma.2012.10.02

Sedov, S., Zazovskaya, E., Fedorov-Davydov, D. and Alekseeva, T. (2019): Soils of East Antarctic oasis: Interplay of organisms and mineral components at microscale. Boletín de la Sociedad Geológica Mexicana, 71(1): 43-63. doi: 10.18268/bsgm2019v71n1a4

SHMELEV, D.G. (2015): Role of cryogenese in the formation of composition of the late quaternary deposits in antarctic oasis and North East Yakutia. Earth Cryosphere, 1: 41-57. 
Simas, F. N. B. (2004): Soil of the Admiralty Bay, King George Island: Chemical, Physical and Mineralogical Properties. Madison: University of Wisconsin, International Workshop on Antarctic Permafrost and Soils, November, 14-18, 2004. 77 p.

Simas, F. N. B., Schaefer, C. E. G. R., Melo, V. F., Guerra, M. B. B., Saunders, M. and Gilkes, R. J. (2006): Clay-sized minerals in permafrost-affected soils (Cryosols) from King George Island, Antarctica. Clays and Clay Minerals, 54(6): 721-736. doi: 0.1346/CCMN.2006.0540607

Sizov, O., Volvakh, A., Molodkov, A., Vishnevskiy, A., Soromotin, A. and Abakumov, E. (2020): Lithological and geomorphological indicators of glacial genesis in the upper Quaternary strata, Nadym River basin, Western Siberia. Solid Earth, 11: 2047-2074. doi: 10.5194/se-11-2047-2020

Slagoda, E. A., Krylov, A. V., Popov, K. A., Opokina, O. L., Drozdov, D. S., Rogov, V. V., Kurchatova, A. N., Orekhov, P. T., Ermak, A. A., Khodzher, T. V., Tomberg, I. V., Suslova, M. Yu., Zhuchenko, N. A. and ABramov, A. A. (2015): Cryolithology of sediments of the have Island, Archipelago Franz Josef Land. Earth Cryosphere, 4: 17-30.

Sokolovska, M., Chipev, N., Ilieva, R., Nusterova, M., Petrova, L., Vergilov, Z., Hristova, R. and BECH, J. (2015): Soils on Livingston Island: Composition, properties and ecological aspects. In: Ch. Pimpirev, N. Chipev (eds.): Bulgarian Antarctic Research - A Synthesis, pp. 308-319. "St. Kliment Ohridski” University Press. (ISBN 978-954-07-3939-7).

STOOPS, G. (2003): Guidelines for analysis and description of soil and regolith thin section. Published by soil Sci. Soc. Am. Inc. Madison, Wisconsin, USA. 184 p.

Stoops, G. (2009): Evaluation of Kubiena's contribution to micropedology. Eurasian Soil Science, 42: 693-698.

StOops, G., Eswaran, H. (1986): Soil micromorphology. New York: Van Nostrands Reinhold Company, $345 \mathrm{p}$.

Vlasov, D. Yu., Abakumov, E. V., Nadporozhskaya, M. A., Kovsh, N. V., Krylenkov, V. A., Lukin, V. V. and Safronova, E. V. (2005): Lithosols of King George Island, western Antarctica. Eurasian Soil Science, 38(7): 681-687.

\section{Web sources / Other sources}

[1] IUSS Working Group WRB (2015): World Reference Base for Soil Resources 2014, update 2015. International soil classification system for naming soils and creating legends for soil maps. World Soil Resources Reports No. 106. Rome: FAO. 